\title{
Idarucizumab w praktyce klinicznej. Krwawienie z przewodu pokarmowego zagrażające życiu u 83-letniej chorej
}

\author{
Idarucizumab in clinical practice. Gastrointestinal bleeding \\ that is life-threatening in an 83-year-old patient
}

\author{
Anna Szpotowicz ${ }^{1}$, Iwona Gorczyca-Michta ${ }^{2}$, Małgorzata Krzciuk ${ }^{1}$, Beata Wożakowska-Kapłon ${ }^{2,3}$ \\ ${ }^{1}$ Oddział Kardiologii Zakład Opieki Zdrowotnej w Ostrowcu Świętokrzyskim \\ ${ }^{2}$ I Klinika Kardiologii i Elektroterapii Świętokrzyskiego Centrum Kardiologii w Kielcach \\ ${ }^{3}$ Wydział Lekarski i Nauk o Zdrowiu Uniwersytetu Jana Kochanowskiego w Kielcach
}

\section{Streszczenie}

Idarucizumab jest swoistym czynnikiem odwracającym działanie dabigatranu, niewywierającym wpływu na inne środki przeciwkrzepliwe. Wiąże się on wyłącznie z dabigatranem i jego metabolitami, przez co neutralizuje ich działanie przeciwzakrzepowe. Jest to pierwszy czynnik odwracający działanie doustnych leków przeciwkrzepliwych, nienależących do grupy antagonistów witaminy $\mathrm{K}$.

Słowa kluczowe: idarucizumab, dabigatran, NOAC, przeciwciało monoklonalne

Folia Cardiologica 2017; 12, 3: 303-305

\section{Wstęp}

W erze leków przeciwkrzepliwych niebędących antagonistami witaminy K (NOAC, non-vitamin $\mathrm{K}$ antagonist oral anticoagulants) [1] przełomowe stało się odkrycie specyficznego fragmentu przeciwciała monoklonalnego o nazwie idarucizumab. Jest to jedyne specyficzne i silne antidotum, które odwraca działanie przeciwkrzepliwe dabigatranu, jednego z najpowszechniej stosowanych NOAC. Idarucizumab łączy się z dabigatranem w 100\%, nawet gdy jest już związany z trombiną i wiąże dabigatran z 350-krotnie większym powinowactwem niż trombina [2-3]. Zastosowanie idarucizumabu jest uzasadnione u chorych leczonych dabigatranem, w sytuacjach gdy potrzebne jest szybkie odwrócenie jego działania.

\section{Opis przypadku}

Przedstawiono opis przypadku kobiety 89-letniej przyjętej do szpitala z powodu zagrażającego życiu krwawienia z przewodu pokarmowego. Pacjentka z wywiadem nadciśnienia tętniczego, choroby wieńcowej, po przebytym udarze niedokrwiennych mózgu, zakrzepicą żył głębokich kończyny dolnej prawej, cukrzycą typ 2, napadowym migotaniem przedsionków (AF, atrial fibrillation). Chora od 3 lat leczona była dabigatranem w dawce zredukowanej $110 \mathrm{mg}$ 2 razy/dobę. Ryzyko zakrzepowo-zatorowe u prezentowanej chorej było duże, w skali $\mathrm{CHA}_{2} \mathrm{DS}_{2}$ VASC chora uzyskała 8 punktów. Także ryzyko krwawienia u prezentowanej chorej było wysokie -3 punkty w skali HAS-BLED. Przy przyjęciu do szpitala stwierdzono masywne krwawienie z przewodu pokarmowego objawiające się smolistymi stolcami oraz śladami świeżej krwi w stolcu. W badaniu przedmiotowym stwierdzono tkliwy, napięty, brzuch, hipotonię, ciśnienie tętnicze wynoszące $85 / 50 \mathrm{~mm} \mathrm{Hg}$ i cechy odwodnienia. W badaniach laboratoryjnych wykazano niedokrwistość stężenie hemoglobiny 7,6 g/dl (norma 12,0-15,6 g/dl), klirens kreatyniny (eGFR, estimated glomerular filtration rate) $40 \mathrm{ml} / \mathrm{min}$ oraz znacznie wydłużony - do $80 \mathrm{~s}$ - czas częściowej tromboplastyny po aktywacji (APTT, 
activated partial thromboplastin time) (norma 26-40 s). Chora regularnie przyjmowała dabigatran od 2 lat, ostatnią dawkę zażyła 4 godziny przed przyjęciem do szpitala. Po konsultacji chirurgicznej wdrożono leczenie objawowe: nawodnienie dożylne oraz omeprazol w dożylnym bolusie. Chorą zakwalifikowano do pilnej transfuzji krwi i badań endoskopowych. Jednocześnie podjęto decyzję o podaniu 5 gramów idarucizumabu w postaci dwóch fiolek, z których każda zawierała 2,5 mg substancji czynnej we wlewie dożylnym trwającym 5 minut, między podaniami zachowano 10-minutową przerwę. W badaniach w 30. minucie od podania idarucizumabu stwierdzono skrócenie się APTT do 35 s i uzyskano stabilizację stanu ogólnego. Wykonano gastroskopię, stwierdzając owrzodzenie błony śluzowej żołądka i dwunastnicy, bez cech czynnego krwawienia. Przetoczono 2 jednostki zgodnego grupowo koncentratu krwinek czerwonych. Włączono doustne leczenie inhibitorem pompy protonowej, suplementację żelaza, zastosowano eradykację Helicobacter pylori. W 3. dobie uzyskano normalizację paramentów krzepnięcia - APTT: 27 s. Wykonano kolonoskopię, nie stwierdzając cech aktywnego krwawienia. Po ocenie stanu ogólnego, rozważeniu ryzyka zakrzepowo-zatorowego podjęto decyzję o ponownym włączeniu w 7. dobie dabigatranu w dawce zredukowanej $110 \mathrm{mg} 2$ razy/dobę. Chora pozostaje w obserwacji, nie podaje cech krwawienia z przewodu pokarmowego. W systematycznie wykonywanych badaniach laboratoryjnych nie obserwuje się obniżenia parametrów czerwonokrwinkowych. Po 2 miesiącach wykonano ponowną gastroskopię, nie stwierdzając czynnego owrzodzenia ani cech aktywnego krwawienia.

\section{Omówienie}

Wzrost ryzyka krwawienia u chorych leczonych NOAC obserwuje się u pacjentów po przedawkowaniu leków przeciwkrzepliwych, a także u tych, którzy stosowali NOAC zgodnie z zaleceniami, w adekwatnej dawce. W retrospektywnym badaniu kohortowym obejmującym 21033 pacjentów z niezastawkowym AF przyjmujących dabigatran ryzyko krwawienia u chorego z AF było istotnie związane z wiekiem - w porównaniu z chorymi w wieku poniżej 55. roku życia u chorych w wieku 64, 65-74 i 75 lub więcej lat uśrednione współczynniki ryzyka (aHR, average hazard ratio) wynosiły, odpowiednio, 1,54 (95-proc. przedział ufności [Cl, confidence interval] 0,89-2,68), 2,72 (95\% Cl 1,59-4,65) oraz 4,52 (95\% Cl 2,68-7,64). Czynnikami predysponującymi do wystąpienia krwawienia w tej obserwacji były: upośledzona funkcja nerek, niewydolność serca, nadużywanie alkoholu, przebyta infekcja Helicobacter pylori, terapia przeciwpłytkowa oraz stosowanie digoksyny [4]. U prezentowanej chorej czynnikami ryzyka wystąpienia krwawienia z górnego odcinka przewodu pokarmowego był podeszły wiek, upośledzona funkcja nerek, polipragmazja, możliwe nadużywanie niesteroidowych leków przeciwzapalnych z powodu dolegliwości kostno-stawowych. W przedstawionym przypadku zdecydowano o podaniu idarucizumabu, dzięki zastosowaniu którego uzyskano natychmiastową możliwość wykonania gastroskopii, co uchroniło chorą przed nieustającym krwawieniem z przewodu pokarmowego i postępującą, zagrażającą życiu anemizacją. Skuteczność i bezpieczeństwo idarucizumabu zostały wykazane w badaniu RE-VERESE $\mathrm{AD}$ (Resersal Effects of Idarucizumab on Active Dabigatran) [4-5]. Do badania włączono 90 chorych. Do grupy A zakwalifikowano chorych z jawnym, niekontrolowanym lub zagrażającym życiu krwotokiem, który decyzją lekarza prowadzącego wymagał podania antidotum. Pacjentów z grupy B poddano zabiegowi chirurgicznemu lub innym procedurom inwazyjnym w trybie pilnym. W grupie $A$ u 18 pacjentów stwierdzono krwawienie wewnątrzczaszkowe, u 20 - krwawienie do przewodu pokarmowego, u 9 - krwotok pourazowy, a u 11 - krwawienie z innych przyczyn. Wszyscy pacjenci otrzymali 5 g idarucizumabu, następnie byli obserwowani co najmniej miesiąc. U wszystkich chorych uzyskano odwrócenie działania dabigatranu, co potwierdzono wynikami badań obejmujących „rozcieńczony" czas trombinowy (dTT, diluted thrombin time) i ekarynowy czas krzepnięcia (ECT, ecarin clothing time). Po czterech godzinach od zastosowania idarucizumabu 83 z 86 pacjentów miało stężenie wolnego dabigatranu bliskie dolnych granic wykrywalności, spadek w porównaniu z wartościami szczytowymi wynosił 80\% [5].

Wesołowska i wsp. [6] opisali także szybkie odwrócenie działania dabigatranu po podaniu idarucizumabu u 93-letniej kobiety z krwawieniem z przewodu pokarmowego. Z kolei Tomaszuk-Kazberuk i wsp. [7] przedstawili chorą z rozwarstwiającym tętniakiem aorty, u której odwrócono działanie dabigatranu za pomocą idarucizumabu.

U prezentowanej chorej po wyleczeniu owrzodzenia błony śluzowej żołądka i dwunastnicy ponownie włączono do leczenia dabigatranem w dawce $110 \mathrm{mg} 2$ razy/dobę. Występowało u niej wysokie ryzyko zakrzepowo-zatorowe i przebyła udar niedokrwienny mózgu, dlatego konieczne było zastosowanie najskuteczniejszej prewencji zdarzeń zakrzepowo-zatorowych. Lauffenburger i wsp. [3] wykazali, że w grupie 446 leczonych dabigatranem , u których wystąpiło krwawienie z przewodu pokarmowego, 43,3\% badanych wróciło do stosowania dabigatranu po tym epizodzie. W badaniu RE-VERESE AD powtórnie podano dabigatran w grupie A w 72\% przypadków po średnim czasie 5,3 dnia, a w grupie B u 90\% pacjentów po średnim czasie 1,2 dnia. Należy podkreślić, że w trakcie podawania idarucizumabu nie obserwowano działań niepożądanych, a podanie leku nie wymagało modyfikowania dawki na podstawie parametrów nerkowych, zaburzenia czynności wątroby ani wieku pacjenta. Zgodnie z charakterystyką produktu leczniczego, 
określającą postępowanie u chorych leczonych NOAC, u których wystąpiło powikłanie krwotoczne, zastosowanie idarucizumabu jest wskazane u chorych leczonych dabigatranem w następujących sytuacjach klinicznych:

- zagrażające życiu krwawienie lub krwawienie w krytycznej lokalizacji;

- duże krwawienie nieustępujące mimo leczenia miejscowego lub wysokie ryzyko nawrotu krwawienia z powodu przedawkowania dabigatranu lub zmniejszenia szybkości jego eliminacji;

- potrzeba pilnej operacji/interwencji związanej z wysokim ryzykiem krwawienia, której nie można opóźnić.

\section{Konflikt interesów}

Autorki nie deklarują konfliktu interesów.

\section{Abstract}

Idarucizumab is a specific agent that reverts the effects of dabigatran while not affecting the activity of other anticoagulants. It selectively binds dabigatran and its metabolites thus neutralizing their anticoagulant activity. Idarucizumab is the first agent to revert the effects of non-vitamin $\mathrm{K}$ antagonist oral anticoagulants.

Key words: idarucizumab, dabigatran, NOAC, monoclonal antibody

Folia Cardiologica 2017; 12, 3: 303-305

\section{Piśmiennictwo}

1. Stępińska J, Wożakowaka-Kapłon B, Pruszczyk P, et al. Doustne antykoagulanty non-VK już nie „nowe”! Kardiol Pol. 2014; 72(9): 854-855, doi: 10.5603/kp.2014.0180.

2. Huisman MV, Lip GYH, Diener HC, et al. Dabigatran etexilate for stroke prevention in patients with atrial fibrillation: resolving uncertainties in routine practice. Thromb Haemost. 2012; 107(5): 838-847, doi: 10.1160/TH11-10-0718, indexed in Pubmed: 22318514.

3. Lauffenburger JC, Rhoney DH, Farley JF, et al. Predictors of gastrointestinal bleeding among patients with atrial fibrillation after initiating dabigatran therapy. Pharmacotherapy. 2015; 35(6): 560-568, doi: 10.1002/phar.1597, indexed in Pubmed: 26044889.

4. Pollack CV. Idarucizumab for dabigatran reversal: updated results of the RE-VERSE AD Study. Presented at 2016 American Heart Association Scientific Sessions 2016. New Orleans, Louisiana, 2016.
5. Styczeń A, Falkiewicz M, Karaś-Głodek M, et al. Eteksylan dabigatranu a idarucizumab. Folia Cardiol. 2016; 11(4): 284-292, doi: 10.5603/ /FC.2016.0049.

6. Wesołowska K, Woronowicz-Chróściel A, Kluk M, et al. Idarucizumab - nowy poziom terapii przeciwkrzepliwe. Opis leczenia powikłań krwotocznych u 93-letniej chorej. Folia Cardiol. 2016; 11: 554-556, doi: 10.5603/FC.2016.0114.

7. Tomaszuk-Kazberuk A, Łopatowska P, Młodawska E, et al. Successful use of idarucizumab as a reversal agent for dabigatran in a patient with acute dissected aortic aneurysm. Pol Arch Intern Med. 2017; 127(1): 68-70, doi: 10.20452/pamw.3918, indexed in Pubmed: 28146465. 